\title{
Small Molecule Recognition and Tools to Study Modulation of r(CGG)exp in Fragile X-Associated Tremor Ataxia Syndrome
}

\author{
Wang-Yong Yang ${ }^{\dagger}$, Fang He ${ }^{\ddagger}$, Rita L. Strack ${ }^{\S}$, Seok Yoon $\mathrm{Oh}^{\ddagger}$, Michelle Frazer ${ }^{\ddagger}$, Samie R. \\ Jaffrey ${ }^{\S}$, Peter K. Todd ${ }^{\ddagger}$, and Matthew D. Disney ${ }^{\dagger}$ \\ tDepartments of Chemistry and Neuroscience, The Scripps Research Institute, 130 Scripps Way, \\ Jupiter, Florida 33458, United States \\ FDepartment of Neurology, University of Michigan, 4005 BSRB, 109 Zina Pitcher Place, Ann \\ Arbor, Michigan 48109-2200, United States \\ $\S$ Department of Pharmacology, Weill Medical College of Cornell University, 1300 York Avenue, \\ Box 70, New York, New York 10065, United States
}

\begin{abstract}
RNA transcripts containing expanded nucleotide repeats cause many incurable diseases via various mechanisms. One such disorder, fragile X-associated tremor ataxia syndrome (FXTAS), is caused by a noncoding $r(\mathrm{CGG})$ repeat expansion $\left(\mathrm{r}(\mathrm{CGG})^{\exp }\right.$ ) that (i) sequesters proteins involved in RNA metabolism in nuclear foci, causing dysregulation of alternative pre-mRNA splicing, and (ii) undergoes repeat associated non-ATG translation (RANT), which produces toxic homopolymeric proteins without using a start codon. Here, we describe the design of two small molecules that inhibit both modes of toxicity and the implementation of various tools to study perturbation of these cellular events. Competitive Chemical Cross Linking and Isolation by Pull Down (C-ChemCLIP) established that compounds bind $\mathrm{r}(\mathrm{CGG})^{\exp }$ and defined small molecule occupancy of $\mathrm{r}(\mathrm{CGG})^{\exp }$ in cells, the first approach to do so. Using an RNA GFP mimic, $r(\mathrm{CGG})^{\exp }$-Spinach2, we observe that our optimal designed compound binds $r(\mathrm{CGG})^{\exp }$ and affects RNA localization by disrupting preformed RNA foci. These events correlate with an improvement of pre-mRNA splicing defects caused by RNA gain of function. In addition, the compounds reduced levels of toxic homopolymeric proteins formed via RANT. Polysome profiling studies showed that small molecules decreased loading of polysomes onto $\mathrm{r}(\mathrm{CGG})^{\text {exp }}$, explaining decreased translation.
\end{abstract}

\section{Graphical abstract}

Correspondence to: Matthew D. Disney.

Author Present Address: Department of Biological and Health Sciences, Texas A\&M University-Kingsville, MSC158, 920 University Blvd. Kingsville, Texas 78363, United States.

Supporting Information: The Supporting Information is available free of charge on the ACS Publications website at DOI: 10.1021/ acschembio.6b00147.

- Tables S1-S4 and Figures S1-S19, Schemes S1-S3, additional synthesis procedures

The authors declare no competing financial interest. 


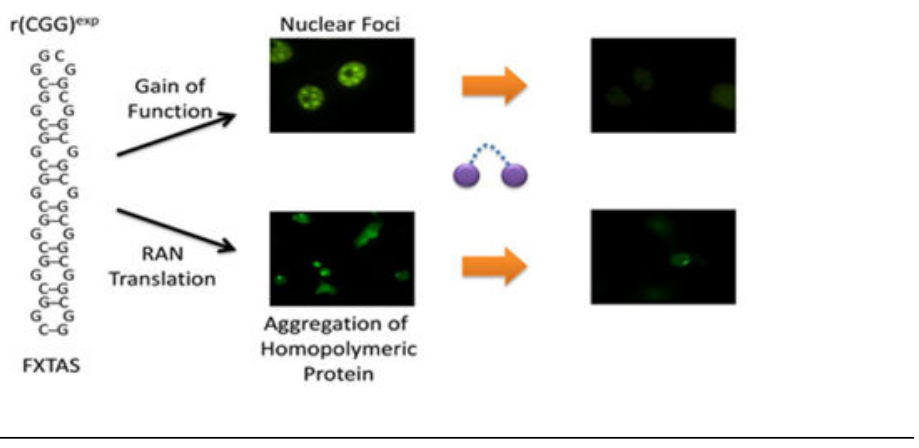

\section{Introduction}

RNA is a central molecule in biological processes and plays important roles in regulation of gene expression.(1) Many regulatory RNAs fine-tune the transcriptome and adjust the proteome. Not surprisingly, RNA mutations, insertions, and deletions are associated with disease, including neuromuscular and neurodegenerative diseases and cancer.(2) Nucleotide repeat expansions cause numerous neurological disorders, $(3,4)$ including a number of dominantly inherited disorders such as fragile $\mathrm{X}$-associated tremor ataxia syndrome (FXTAS), myotonic dystrophy (DM), and amyotrophic lateral sclerosis (ALS) and frontotemporal dementia (FTD), where the repeats reside outside of a predicted protein coding region.

FXTAS is a late onset (over age 50) neurological condition that affects balance, tremor, and memory and affects 1 in 3000 men and 1 in 5000 women. $(5,6)$ It is caused by an expanded $\mathrm{r}(\mathrm{CGG})$ repeat $\left(\mathrm{r}(\mathrm{CGG})^{\mathrm{exp}}\right.$; 55-200 repeats) in the $5^{\prime}$ untranslated region (UTR) of the fragile X mental retardation 1 (FMRI) gene located on the X chromosome.(7-9) Gain of function of $\mathrm{r}(\mathrm{CGG})^{\exp }$ is a pathogenic mechanism of FXTAS, akin to myotonic dystrophy. (10) Evidence for RNA gain of function comes from animal models and cell-based assays. For example, insertion of untranslated $\mathrm{r}(\mathrm{CGG})^{\exp }$ of pathogenic length into mice and Drosophila causes deleterious effects observed in disease-affected patients. $(11,12)$ In cellbased models, $\mathrm{r}(\mathrm{CGG})^{\exp }$ forms nuclear inclusions, and the size of the inclusions scales with the length of the repeat and the age of death from disease. $(13,14)$ A more detailed mechanism for the RNA gain of function has been elucidated from studies of patient-derived tissues and model cell lines. In studies by the Charlet group, it was shown that $\mathrm{r}(\mathrm{CGG})^{\exp }$ first binds DiGeorge syndrome critical region 8 (DGCR8),(15) a protein involved in microRNA biogenesis, followed by recruitment of the Src-Associated substrate during mitosis of $68 \mathrm{kDa}$ (Sam68) protein.(10) The RNA-protein complex is a scaffold for the assembly of other proteins such as muscleblind-like 1 protein (MBNL1) and heterogeneous nuclear ribonucleoprotein (hnRNP) A2/B1. Sam68 is a nuclear RNA-binding protein that regulates alternative pre-mRNA splicing.(16) Sequestration of Sam68, MBNL1, and hnRNP A2/B1 by $r(C G G)^{\exp }$ in nuclear foci leads to pre-mRNA splicing defects (Figure 1A).(10)

A protein-mediated neurodegeneration mechanism also operates within FXTAS.(17) The Todd group showed that $\mathrm{r}(\mathrm{CGG})^{\exp }$ triggers repeat associated non-ATG translation (RANT). (17) In RANT, a repeat such as $r(\mathrm{CGG})^{\exp }$ is translated without the use of an AUG start codon, producing toxic polymeric proteins that contribute to disease.(18) In FXTAS, RANT 
produces a toxic polyglycine-containing protein, FMRpolyG (Figure 1B), that contributes to neurodegeneration and pathogenesis.(17) Interestingly, genome-wide association studies have shown that non-ATG initiated translation is not a rare event and occurs in many systems outside of a disease context. $(18,19)$ Thus, small molecules that inhibit non-ATG translation could have broad utility as chemical probes to study the roles of such translational events in cells.

Compounds that bind directly to $\mathrm{r}(\mathrm{CGG})^{\exp }$ could potentially inactivate both pathogenic mechanisms: protein sequestration and RANT (Figure 1C). Previously, a hydroxyellipticine derivative, 1a, was identified as a compound that displaces proteins bound to $\mathrm{r}(\mathrm{CGG})^{\exp }$ in vitro with a low micromolar $\mathrm{IC}_{50}$. (20) Compound $1 \mathrm{a}$ also improved pre-mRNA splicing defects and inhibited formation of nuclear inclusions in a FXTAS cellular model.(20) Herein, we show that 1a inhibits RANT in a FXTAS cellular model as well. We also describe the development of dimeric versions of 1a that affect these processes and use the two small molecules as chemical probes to study how $\mathrm{r}(\mathrm{CGG})^{\exp }$ biology is perturbed, including RANT. Further, the effect of compound binding on the localization of $\mathrm{r}(\mathrm{CGG})^{\exp }$ was measured in live cells, showing that the time required to disrupt foci is correlated to the time required for improvement of pre-mRNA splicing defects. Importantly, we also describe a chemical approach that allows study of the occupancy of RNA targets by small molecules directly in cells. Our studies suggest that the potency of small molecules is affected by its ability to occupy the desired RNA target, which is a function of its binding affinity, its ability to cross cellular membranes, and other factors.

\section{Results \& Discussion}

\section{Synthesis of a r(CGG) exp-Binding Compound (Module) Suitable for Modular Assembly}

$\mathrm{r}(\mathrm{CGG})^{\exp }$ folds into a hairpin that displays multiple copies of $5^{\prime} \mathrm{CGG} / 3^{\prime} \mathrm{GGC}(1 \times 1$ nucleotide internal loop) motifs (Figure 1). By displaying several copies of a small molecule that binds this repeating motif on the same backbone, $(4,27)$ high affinity and selective compounds can be designed to target $\mathrm{r}(\mathrm{CGG})^{\mathrm{exp}}$. We previously identified that 1a (Figure $2 \mathrm{~A}$ ) binds $5^{\prime} \mathrm{CGG} / 3^{\prime} \mathrm{GGC}$ motifs and improves $\mathrm{r}(\mathrm{CGG})^{\exp }$-associated defects in cellular models.(20) Previous structure-activity relationship studies(20) informed the ideal placement of an alkyne functional group (affording 9-hydroxy- $N$-propargylellipticine; HEalkyne; Figure 2B and Scheme S1) for conjugation to an azide-functionalized polymeric ( $N$ methyl peptide) backbone (Figure 2B and Scheme S2). Previously, we showed that $N$ methyl peptide backbones provide near ideal properties as a multivalent display scaffold.(28) In order to determine the optimal distance between HE RNA-binding modules to bind $\mathrm{r}(\mathrm{CGG})^{\exp }$, a library of compounds was synthesized that display two HE-alkyne modules separated by different distances, or 2HE-nNMe (Figure 2B and Scheme S3).

\section{Screening Dimeric Compounds for Inhibiting the $(\mathrm{CGG})_{12}$-DGCR8 $\triangle$ Complex}

We employed a previously reported TR-FRET assay to study compound potency for inhibiting the $\mathrm{r}(\mathrm{CGG})_{12}$-DGCR8 $\Delta$ complex.(20) We screened the library of dimers, 2HE-1NMe-2HE-6NMe, at $1 \mu \mathrm{M}$ concentration (Figure S1). 2HE-5NMe was the most potent compound, inhibiting $\sim 60 \%$ of the $\mathrm{r}(\mathrm{CGG})_{12}$-DGCR $8 \Delta$ complex. We next measured 
the potency of 2HE-5NMe in the absence and presence of tRNA (62-fold excess over $\mathrm{r}(\mathrm{CGG})_{12}$ ), affording $\mathrm{IC}_{50}$ 's of $0.5 \mu \mathrm{M}$ and $3.5 \mu \mathrm{M}$, respectively (Figure $\mathrm{S} 2$ ). This corresponds to a $\sim 7$-fold improvement over $\mathbf{1 a}$ ( $\mathrm{IC}_{50}$ of $3.8 \mu \mathrm{M}$ in the absence of tRNA and $20.1 \mu \mathrm{M}$ in the presence of tRNA).

\section{Binding of $1 \mathrm{a}$ and $2 \mathrm{HE}-5 \mathrm{NMe}$ to $\mathrm{r}(\mathrm{CGG})_{12}$}

The affinities, association rates, and dissociation rates of $\mathbf{1 a}$ and $\mathbf{2 H E - 5 N M e ~ w i t h ~} \mathbf{r}(\mathrm{CGG})_{12}$ were measured by biolayer interferometry (BLI). The experimental data sets for both compounds best fit to a 2:1 heterogeneous ligand model, and the results are summarized in Table 1. For 1a, two binding modes with different $K_{\mathrm{d}}$ 's, $800 \mathrm{nM}$ and $55 \mu \mathrm{M}$, were observed. In contrast, 2HE-5NMe showed two binding modes with similar $K_{\mathrm{d}}$ 's of $50 \mathrm{nM}$ and $65 \mathrm{nM}$, $\sim 15$-fold higher affinity than those of $\mathbf{1 a}$ when compared to its highest affinity binding mode. The first binding mode of $\mathbf{2 H E - 5 N M e ~ h a s ~ a n ~ a p p r o x i m a t e l y ~} 10$-fold faster association rate $\left(k_{\mathrm{on}}\right)$ and an approximately 2 -fold slower dissociation rate $\left(k_{\mathrm{off}}\right)$ than 1a's first binding mode. That is, the dimeric compound has a longer residence time than the monomer, which can be beneficial for drug activity. The faster association rate could be due to having two sites that can make productive binding collisions with the target and/or improved preorganization of the dimeric compound for binding RNA. A competition dialysis experiment was completed to further assess binding selectivity and showed that 2HE-5NMe binds $\mathrm{r}(\mathrm{CGG})_{12}$ but does not bind a fully paired control RNA or DGCR8 $\Delta$ (Figure S3).

\section{1a and 2HE-5NMe Increase the Thermal Stability of $r(C G G)_{12}$}

Next, we studied the increase in $\mathrm{r}(\mathrm{CGG})_{12}$ thermal stability $(1 \mu \mathrm{M})$ as a function of $\mathbf{1 a}$ and 2HE-5NMe concentration. Note, $r(\mathrm{CGG})_{12}$ contains five $1 \times 1$ GG nucleotide internal loop binding sites, with two of the $\mathrm{r}(\mathrm{CGG})$ repeats occupying the hairpin loop. For the dimeric compound $2 \mathrm{HE}-5 \mathrm{NMe}$, the enhancement in thermal stability plateaus at $1 \mu \mathrm{M}$ compound; no additional increase in stability is observed when 2.5 or $5 \mu \mathrm{M}$ 2HE-5NMe is added (Figure 3). In contrast, the thermal stability of $\mathrm{r}(\mathrm{CGG})_{12}$ increased as a function of $\mathbf{1 a}$ concentration, up to $5 \mu \mathrm{M}$ (Figure 3), suggesting that all sites in $\mathrm{r}(\mathrm{CGG})_{12}$ are occupied. The resulting thermodynamic parameters from analysis of the optical melting curves are shown in Table 2. While the changes in melting temperature caused by $\mathbf{2 H E - 5 N M e}$ and $1 \mathbf{a}$ are moderate, 2 and $3{ }^{\circ} \mathrm{C}$, respectively, significant differences in $\Delta \Delta G_{37^{\circ}}$ are observed. 2HE-5NMe and 1a increase the thermodynamic stability of $\mathrm{r}(\mathrm{CGG})_{12}$ by 0.9 and $1.4 \mathrm{kcal} /$ mol, respectively, corresponding to as much as an order of magnitude in the equilibrium constant favoring the folded state. We previously reported another dimeric compound, $2 \mathbf{H}-\mathbf{5}$ (Figure S4), that binds r(CGG) ${ }^{\text {exp }}$. Although $\mathbf{2 H - 5}$ improves alternative pre-mRNA splicing defects, (29) it does not inhibit RANT.(21) Interestingly, $\mathbf{2 H - 5}$ has only a slight effect $\left(0.4{ }^{\circ} \mathrm{C}\right)$ on the thermal stability of $\mathrm{r}(\mathrm{CGG})_{12}$ (Figure 3 ).

\section{Studying the Cellular Targets of $1 \mathrm{a}$ and $2 \mathrm{HE}-5 \mathrm{NMe}$}

To validate that 1a and 2HE-5NMe indeed bind $\mathrm{r}(\mathrm{CGG})^{\exp }$ in cells, we used a reactive version of 1a, 1a-CA-Biotin (Figure 2C), as a probe to implement Chemical Cross-Linking and Isolation by Pull-down (Chem-CLIP).(21, 30) 1a-CA-Biotin has a reactive module 
(CA) to covalently bind to its RNA targets and a purification tag (Biotin) to allow for their facile isolation (Figure 2C). Cells were treated with $2.5 \mu \mathrm{M}$ 1a-CA-Biotin, and cellular targets were isolated using streptavidin-coated resin. Bound targets were released from the resin and analyzed via qRT-PCR (Figure 2D). Relative to the starting total RNA, a 5-fold enrichment of $\mathrm{r}(\mathrm{CGG})_{88}$-GFP was observed in the pulled down fractions from cells treated with 1a-CA-Biotin. Although the enrichment of $\mathrm{r}(\mathrm{CGG})_{88}$-GFP is modest, it is likely due to nonselective reaction of the CA moiety, which can be controlled for by Competitive ChemCLIP (C-Chem-CLIP) experiments described below.

To assess the selectivity of 1a-CA-Biotin, we measured the enrichment of highly abundant cellular RNAs(24) and RNAs with at least five consecutive r(CGG) repeats in the human transcriptome in the pulled-down fraction (Figure S5 and Table S3). Modest enrichment (>2fold) was only observed for RNAs containing $\mathrm{r}(\mathrm{CGG})$ repeats; importantly, the great enrichment was observed for r(CGG) 88 (Figure S5).

We also completed a Competitive Chem-CLIP (C-Chem-CLIP) experiment to assess, in cells, (i) if the noncovalent binders 1a and 2HE-5NMe bind to (CGG $_{88}$-GFP and (ii) the RNA target's occupancy. Cells were cotreated with a noncovalent binder (1a or 2HE-5NMe) and 1a-CA-Biotin, and depletion of $\mathrm{r}(\mathrm{CGG})_{88}$-GFP captured by 1a-CA-Biotin was measured. Indeed, 1a and 2HE-5NMe reduced the amount of r(CGG) ${ }^{\text {exp }}$ pulled down by 1aCA-Biotin; the amount required to reduce levels by $50 \%$ was $\sim 420 \mathrm{nM}$ and $\sim 140 \mathrm{nM}$ for 1a and 2HE-5NMe, respectively (Figure 2E). These results show that 1a and 2HE-5NMe compete with 1a-CA-Biotin for binding r(CGG) ${ }^{\exp }$ and that 2HE-5NMe has 3-fold higher occupancy of the target RNA than 1a in cells ( $420 \mathrm{nM}$ vs $140 \mathrm{nM}$ ). Interestingly, the difference in cellular occupancy observed for 1a and 2HE-5NMe is not reflective of differences observed in vitro as assessed by either binding affinity (15-fold) or potency for inhibition of the $\mathrm{r}(\mathrm{CGG})^{\mathrm{exp}}$-DGCR8 complex (7-fold), which could be due to decreased cellular uptake of the dimer. However, these are important considerations for which the CChem-CLIP approach accounts. Collectively, these studies demonstrate the power of the Chem-CLIP approach for target validation and to study target occupancy in cells. Since $\mathrm{r}(\mathrm{CGG})^{\exp }$ is indeed occupied by our small molecules in cells, we next studied their effects on FXTAS-associated defects.

\section{Improvement of pre-mRNA Splicing Defects}

We tested the potency of $\mathbf{2 H E - 5 N M e , ~ a s ~ d e t e r m i n e d ~ b y ~ i m p r o v e m e n t ~ o f ~ p r e - m R N A ~ s p l i c i n g ~}$ defects, using a FXTAS cellular model. In FXTAS, r(CGG) $)^{\exp }$ binds and sequesters Sam68, a pre-mRNA splicing regulator.(10) Sequestration of Sam68 causes its inactivation and hence dysregulation of alternative pre-mRNA splicing. In particular, the alternative splicing of exon 7 of the survival motor neuron 2 pre-mRNA ( SMN2; involved in maintenance of motor neurons and mRNA processing) is dysregulated.(10) Exon 7 is included too frequently when $\mathrm{r}(\mathrm{CGG})^{\text {exp }}$ is expressed, $\sim 70 \%$ of the time vs $\sim 40 \%$ in non-FXTAS cells (Figure 4A). At $50 \mu \mathrm{M}$ concentration, 2HE-5NMe restores alternative pre-mRNA splicing patterns back to wild type (Figure 4B), a 10-fold improvement over 1a.(20) Importantly, 2HE-5NMe does not affect alternative splicing in non-FXTAS-affected cells (Figure S6) or the alternative splicing of pre-mRNAs not regulated by Sam68 (cardiac troponin T (cTNT) 
and pleckstrin homology domain containing, family $\mathrm{H}$ member 2 (PLEKHH2); Figure S7). These results suggest that improvement of the $S M N 2$ pre-mRNA splicing defect is due to 2HE-5NMe binding $\mathrm{r}(\mathrm{CGG})_{60}$ and displacing proteins from it or preventing protein binding. The enhanced potency of the dimer is greater than the differences in target occupancy identified by using C-Chem-CLIP. This may be due to the greater residence time of the dimer (Table 1) and/or the greater surface covered by the dimer, among other factors.

\section{Nuclear Foci}

Another phenotype of cells expressing $\mathrm{r}(\mathrm{CGG})^{\exp }$ is the formation of nuclear foci.(10) Two different assays were completed to determine if $\mathbf{2 H E - 5 N M e ~ a f f e c t s ~ f o c i ~ f o r m a t i o n . ( 2 6 ) ~ I n ~}$ the first assay, 2HE-5NMe was applied to cells shortly after transfection with a plasmid expressing (CGG)60-Spinach2, an RNA GFP mimic,(26) to assess the compound's ability to inhibit foci formation. In a second set of experiments, cells were treated with the compound $24 \mathrm{~h}$ post-transfection to determine if the compound can disrupt preformed foci. Previous reports showed compound 1a inhibits foci formation but cannot disrupt existing foci.(26) In contrast, treatment with $50 \mu \mathrm{M} 2 \mathrm{HE}-5 \mathrm{NMe}$ for $24 \mathrm{~h}$ prevents $\sim 75 \%$ of nuclear foci formation and disrupts $\sim 60 \%$ of preformed foci (Figure $5 \mathrm{~A}$ ). The ability of $\mathbf{2 H E - 5 N M e ~ t o ~}$ disrupt foci is likely due to its greater affinity for $\mathrm{r}(\mathrm{CGG})^{\exp }$ and its longer residence time compared to 1a (Table 1).

Additional experiments were completed to measure how quickly 2HE-5NMe dissolves nuclear foci. Most foci were dissolved within the first hour and fully disappeared by $4 \mathrm{~h}$ (Figure 5B). Since pre-mRNA splicing regulatory proteins are sequestered in foci, we compared the rate of splicing improvement to the rate of foci disappearance. Interestingly, we find a direct correlation between the rate of foci disruption and improvement of premRNA splicing defects with 2HE-5NMe. The compound rescued $~ 50 \%$ of the SMN2 splicing defect in $1 \mathrm{~h}$ and fully rescued the defect in $4 \mathrm{~h}$ (Figure 5C).

\section{Inhibition of RANT}

Next, we studied the inhibition of RANT of a r(CGG) $)^{\text {exp }}$-containing transcript by $\mathbf{1 a}$ and 2HE-5NMe. For these studies, we employed a cellular model system in which $\mathrm{r}(\mathrm{CGG})_{88}$ is embedded in the $5^{\prime}$ UTR of green fluorescent protein (GFP).(17) The construct was developed such that the orientation of the $\mathrm{r}(\mathrm{CGG})$ in the $5^{\prime}$ UTR relative to the GFP open reading frame (ORF) mimics that between $\mathrm{r}(\mathrm{CGG})^{\exp }$ and the ORF in FMR1. Two translation products are observed in cells, the canonical translation product GFP and the RANT product polyG-GFP. The two products can be resolved by SDS-PAGE and visualized by Western blot with an anti-GFP antibody. $(17,21)$

While 2HE-5NMe showed more potent activities in pre-mRNA splicing and nuclear foci than 1a, both 1a and 2HE-5NMe showed similar extents of inhibition of RANT, 80\% inhibition at $50 \mu \mathrm{M}$ (Figure 6A). Importantly, no statistically significant effect on the translation of GFP produced from the canonical translational start site was observed (Figure 6A). Additionally, 1a and 2HE-5NMe do not affect (CGG) ${ }_{88}$-GFP mRNA levels as assessed by qRT-PCR (Figure S8), and no cytotoxicity of the compounds was detected (Figure S9). Taken together, it is possible to inhibit RANT of an expanded repeat embedded in a $5^{\prime}$ UTR 
with a small molecule without significantly affecting the downstream ORF. It was previously shown that oligonucleotides that target $r(\mathrm{CGG})^{\text {exp }}$ in cells affect downstream ORF translation.(31) Thus, a small molecule approach to target $r(\mathrm{CGG})^{\exp }$ in FXTAS appears to have functional benefits over oligonucleotides in addition to the advantage of facile lead optimization.

Interestingly, the compounds' inhibitory effects on RANT correlate with their ability to increase the thermal stability of $\mathrm{r}(\mathrm{CGG})^{\exp }$, even though the affinity of 2HE-5NMe for $\mathrm{r}(\mathrm{CGG})^{\exp }$ is higher than 1a's and the two compounds have similar occupancy for the target at the concentrations that inhibit RANT. Although many factors could affect RANT, it appears in this case that enhanced thermal stability of the target imparted by small molecule binding to $\mathrm{r}(\mathrm{CGG})^{\exp }$ is important to effectively inhibit RANT. In additional support of thermodynamic effects playing roles in RANT, it has been previously shown that longer $\mathrm{r}(\mathrm{CGG})$ repeats (more thermodynamically stable) have lower RAN translational efficiency than shorter ones (less thermodynamically stable).(31) If simple statistical effects were solely at play, a longer repeating RNA would form more RANT products than shorter ones.

Since RANT products ((FMRpolyG) form nuclear inclusions in a repeat length-dependent manner,(17) the effect of 1a treatment on FMRpolyG-GFP inclusions was measured. We observed a dose-dependent effect $(1-100 \mu \mathrm{M})$ of the compound on inclusion number both 24 and $48 \mathrm{~h}$ post-treatment (Figure 6B). Statistically significant reductions of inclusions were observed when cells were treated with 10 or $100 \mu \mathrm{M} \mathrm{1a}$, with a maximal decrease ( 40\%) observed $48 \mathrm{~h}$ post-treatment of $100 \mu \mathrm{M} 1 \mathrm{a}$ (Figure 6B).

\section{Effect of 1a on Ribosome Loading onto r(CGG) ${ }^{\exp }$-Containing mRNA}

Since 1a and 2HE-5NMe inhibited RANT to a similar extent, we used polysome profiling to assess the loading of ribosomes onto $\mathrm{r}(\mathrm{CGG})^{\text {exp }}$ in untreated and 1a-treated cells. For these experiments, an RNA construct without an ATG start codon, $\mathrm{r}(\mathrm{CGG})_{88}$-(No ATG)-GFP, was utilized such that only loading onto the repeats to initiate translation could be assessed.(21) We first tested the inhibition of RANT by 1a and 1a-CA-Biotin in this system: 70\% and $\sim 40 \%$ of polyG-GFP expression were inhibited by $50 \mu \mathrm{M}$ of $1 \mathrm{a}$ and $5 \mu \mathrm{M}$ of 1a-CA-Biotin, respectively (Figure S11). Interestingly, since GFP is only translated by RANT (polyGGFP), this system has potential as a high throughput screening method to measure RANT by GFP fluorescence.

Next, the effects of the compounds on ribosome loading were measured as previously reported.(21) In the absence of compound, $~ 75 \%$ of $r(\mathrm{CGG})_{88}$-(No ATG)-GFP is bound by polysomes, that is actively RAN translated. 1a and 1a-CA-Biotin reduced the amount of $\mathrm{r}(\mathrm{CGG})_{88}$-(No ATG)-GFP in polysomes by $\sim 25 \%$ and $\sim 13 \%$, respectively (Figure 7 ). Importantly, the abundance of $\beta$-actin mRNA in polysomes showed no change after compound treatment, indicating compounds do not globally affect translation. As expected, polyG-GFP levels were proportional to the abundance of mRNA in polysomes. Taken together, the compounds bind to $r(\mathrm{CGG})^{\text {exp }}$ and prevent ribosome loading to the $\mathrm{r}(\mathrm{CGG})^{\text {exp }}$, resulting in inhibition of toxic protein expression. 


\section{Conclusion}

We have demonstrated that designer, modularly assembled small molecules that bind $\mathrm{r}(\mathrm{CGG})^{\exp }$ potently improve FXTAS-associated defects in cells. Further, these studies have revealed features in small molecules that are important for inhibiting two different modes of RNA repeat expansion toxicity, both gain of function and RANT. Our data suggest that small molecule affinity and target occupancy are important for inhibiting $\mathrm{r}(\mathrm{CGG})^{\exp }$ gain of function in which proteins are sequestered in nuclear foci. In contrast, increasing the thermal stability of $\mathrm{r}(\mathrm{CGG})^{\exp }$ is important for inhibiting RANT, which could proceed by preventing ribosome binding or inducing ribosome stalling by preventing unwinding of $\mathrm{r}(\mathrm{CGG})^{\exp }$ structure required for translation.

\section{Materials \& Methods}

\section{Chemical Synthesis}

Details of compound syntheses and characterization are provided in the Supporting Information.

\section{Time-Resolved Fluorescence Resonance Energy Transfer (TR-FRET) Assay}

The in vitro activity of modularly assembled compounds was assessed by inhibition of the $\mathrm{r}(\mathrm{CGG})_{12}$-DGCR8 $\Delta$ complex using a previously reported TR-FRET assay.(20, 21) Where indicated, an 62-fold excess of full length bulk yeast tRNA was added.

\section{Biolayer Interferometry (BLI)}

BLI was used to measure the binding affinities, association rates, and dissociation rates of compounds and $\mathrm{r}(\mathrm{CGG})_{12} .5^{\prime}$-Biotinylated $\mathrm{r}(\mathrm{CGG})_{12}(60 \mathrm{nM})$ was folded in $1 \times$ Kinetics Buffer (ForteBio) by heating at $95{ }^{\circ} \mathrm{C}$ for $5 \mathrm{~min}$ and slowly cooling to RT. The RNA (200 $\mu \mathrm{L}$ aliquots) was then added to a black 96-well plate (Greiner Bio-One). The compound of interest at varying concentrations ( $200 \mu \mathrm{L}$ aliquots) was dissolved in $1 \times$ Kinetics Buffer. A sample with no compound was used as the background. All experiments were performed at $30^{\circ} \mathrm{C}$ with agitation set to $1000 \mathrm{rpm}$.

Data analyses and curve fitting were completed using Octet Data Analysis, version 7.0. Experimental data were fitted using the 2:1 heterogeneous ligand (HL) curve fit. Global analysis of all data sets acquired for different compound concentrations, assuming reversible binding, was completed using nonlinear least-squares fitting.

\section{Competition Dialysis}

Competition dialysis was completed as previously described.(22) Briefly, $2 \mu \mathrm{M}$ RNA or protein was transferred into Slide-a-Lyzer MINI dialysis units with a molecular weight cutoff of 2000 (Thermo Scientific), and the units were placed into a solution of $1 \mu \mathrm{M}$ ligand. Two blank units containing only buffer were used to monitor equilibration. After the blank units reached equilibrium, sodium dodecyl sulfate (SDS) was added to a final concentration of $1 \%(\mathrm{w} / \mathrm{v})$, and absorbance was measured. Absorbance was used to determine total ligand concentration $\left(C_{\mathrm{t}}\right)$. The concentration of the dialysate (free ligand concentration, $C_{\mathrm{f}}$ ) was 
determined analogously. The bound ligand concentration $\left(C_{\mathrm{b}}\right)$ was then determined using eq 1 :

$$
\mathrm{C}_{\mathrm{b}}=\mathrm{C}_{\mathrm{t}}-\mathrm{C}_{\mathrm{f}}
$$

where $C_{\mathrm{b}}, C_{\mathrm{t}}$, and $C_{\mathrm{f}}$ are concentrations of bound, total, and free ligand, respectively.

\section{Stabilization of $r(C G G)_{12}$ upon Binding to Compound}

A $1 \mu \mathrm{M}$ sample of $\mathrm{r}(\mathrm{CGG})_{12}$ in $2 \mathrm{mM} \mathrm{Na}_{2} \mathrm{HPO}_{4}$ (pH 7.0), $45 \mathrm{mM} \mathrm{NaCl}$, and $25 \mu \mathrm{M}$ $\mathrm{Na}_{2}$ EDTA was heated at $95{ }^{\circ} \mathrm{C}$ for $1 \mathrm{~min}$ and then slowly cooled to RT. Compound was then added at various concentrations $\left(1 \mu \mathrm{M}, 2.5 \mu \mathrm{M}\left(1: 1\right.\right.$ ratio of $\mathbf{2 H E}-5 \mathrm{NMe} / 5^{\prime} \mathrm{CGG}^{\prime}$ '/ $3^{\prime}$ GGC5 $^{\prime}$ binding sites in $\left.\mathrm{r}(\mathrm{CGG})_{12}\right)$, and $5 \mu \mathrm{M}\left(1: 1\right.$ ratio of $1 \mathrm{a} / 5^{\prime} \mathrm{CGG}^{\prime} / 3^{\prime} \mathrm{GGC}^{\prime}$ in $\left.\mathrm{r}(\mathrm{CGG})_{12}\right)$ ). The mixtures were incubated at RT for $10 \mathrm{~min}$. Optical melting experiments were then completed using a Beckman Coulter DU800 UV-vis spectrophotometer with an attached Peltier heater. A heat rate of $1{ }^{\circ} \mathrm{C} / \mathrm{min}$ was applied, and absorbance at $260 \mathrm{~nm}$ was measured. Melting curves were fit to a self-complementary model using MeltWin 3.5 software.(23) The program fits each curve and calculates thermodynamic parameters and melting temperature $\left(T_{\mathrm{m}}\right)$.

\section{Target Validation: Chem-CLIP \& C-Chem-CLIP}

COS7 cells were grown in growth medium $(1 \times$ DMEM, $10 \%$ FBS, and $1 \times$ GlutaMax (Invitrogen)) as monolayers in a $75 \mathrm{~cm}^{2}$ flask to $\sim 95 \%$ confluency. Cells were transfected with a plasmid encoding $(\mathrm{CGG})_{88}$-GFP ${ }^{17}$ using Lipofectamine 2000 (Invitrogen) per the manufacturer's recommended protocol. After $5 \mathrm{~h}$ of incubation, the transfection cocktail was removed and replaced with growth medium containing $2.5 \mu \mathrm{M}$ 1a-CA-Biotin. For C-ChemCLIP, cells were treated with $2.5 \mu \mathrm{M}$ 1a-CA-Biotin and varied concentrations of compound of interest. The cells were then incubated at $37^{\circ} \mathrm{C}$ for $18-20 \mathrm{~h}$. Total RNA was extracted by using Trizol reagent (Ambion) according to the manufacturer's protocol. After RQ1 DNase (Promega) treatment, total RNA was phenol:chloroform extracted and ethanol precipitated. Approximately $100 \mu \mathrm{g}$ of total RNA was incubated with streptavidin beads (100 $\mu \mathrm{L}$, SigmaAldrich) in $1 \times \mathrm{PBS}(\mathrm{pH} 7.4)$ for $2 \mathrm{~h}$ at RT with gentle shaking. The solution was removed, and the beads were washed with $5 \times 200 \mu \mathrm{L}$ of $\mathrm{H}_{2} \mathrm{O}$ for $5 \mathrm{~min}$ each, until the presence of RNA was no longer detected in the wash solution as determined by absorbance at 260 and $280 \mathrm{~nm}$ using a Nanodrop 2000C spectrophotometer (Thermo Scientific). Bound RNA was released from the beads by heating in $1 \times$ Elution Buffer $(100 \mu \mathrm{L}, 95 \%$ formamide, $10 \mathrm{mM}$ EDTA, pH 8.2) at $65^{\circ} \mathrm{C}$ for $5 \mathrm{~min}$. The released RNA was purified by a Quick-RNA MiniPrep Kit (Zymo Research), and cDNA was generated from 50 ng of RNA using a qScript cDNA Synthesis Kit (Quanta Biosciences) per the manufacturer's protocol. qPCR was performed on an ABI 7900 HT Real-Time PCR System. Primer sequences for GFP mRNA and 18S rRNA are provided in Table S1. 


\section{Profiling of Cellular RNAs Pulled down by 1a-CA-Biotin}

HeLa cells in $10 \mathrm{~cm}$ dishes at $\sim 90 \%$ confluency were transfected with a plasmid encoding $(\mathrm{CGG})_{88^{-}} \mathrm{GFP}^{17}$ using Lipofectamine 2000 (Invitrogen) per the manufacturer's recommended protocol. After $5 \mathrm{~h}$ of incubation, the transfection cocktail was removed and replaced with growth medium containing $2.5 \mu \mathrm{M}$ 1a-CA-Biotin. Cells were harvested 18-24 $\mathrm{h}$ post-transfection, and total RNA was extracted by using Trizol reagent (Ambion) according to the manufacturer's protocol. Pull-down was performed as described above except all reagent amounts were scaled up by 5 -fold, and cDNA was generated from $2 \mu \mathrm{g}$ of bound RNA. We profiled 54 highly abundant RNAs, including rRNAs and mRNAs, which were selected based on a previous report.(24) The list of RNAs profiled and primer sequences are listed in Tables S3 and S4. The seven mRNAs that contain at least five consecutive (CGG) repeats were identified by searching NCBI using the nucleotide BLAST function. Primer sets for mRNAs were obtained from RTPrimerDB25 and qPrimerDepot (http://primerdepot.nci.nih.gov). The relative fold enrichment of each RNA pulled down by the compound was calculated with $C_{\mathrm{t}}$ values from qPCR after normalization to $18 \mathrm{~S}$ rRNA.

\section{Improvement of FXTAS-Associated Splicing Defects in a Cellular Model by Using RT-PCR}

In order to determine if compounds improve FXTAS-associated alternative pre-mRNA splicing defects, two different constructs that express $r(\mathrm{CGG})^{\exp }$ were used, $r(\mathrm{CGG})_{60}(20)$ and $\mathrm{r}(\mathrm{CGG})_{60}$-Spinach2.(26) Briefly, either $\mathrm{r}(\mathrm{CGG})_{60}$ or $\mathrm{r}(\mathrm{CGG})_{60}$-Spinach2 were cotransfected with an $S M N 2$ mini-gene that reports on alternative splicing(10) into COS7 cells using Lipofectamine 2000 per the manufacturer's recommended protocol.

For the $\mathrm{r}(\mathrm{CGG})_{60}$ construct, the transfection cocktail was removed after $5 \mathrm{~h}$ and replaced with a growth medium containing the compound of interest. Total RNA was harvested $24 \mathrm{~h}$ later using a Zymo Quick-RNA mini-prep kit. RT-PCR analysis of SMN2 alternative splicing was completed as previously described.(20) Sequences of primers are provided in Table S1.

For the $\mathrm{r}(\mathrm{CGG})_{60}-$ Spinach2 construct, cells were treated with $\mathbf{2 H E - 5 N M e}$ in growth medium $24 \mathrm{~h}$ post-transfection. At different time points $(0,1,2,3$, and $4 \mathrm{~h})$, total RNA was extracted and analyzed for improvement in $S M N 2$ pre-mRNA splicing defects as described above.

\section{Quantifying Nuclear Foci in a FXTAS Cellular Model}

In order to test if 2HE-5NMe inhibits the formation of nuclear foci in a FXTAS cellular system, the $\mathrm{r}(\mathrm{CGG})_{60}$-Spinach2 construct was used.(26) Briefly, COS7 cells were transfected with $(\mathrm{CGG})_{60}$-Spinach2 plasmid using Lipofectamine 2000 transfection reagent per the manufacturer's recommended protocol. After $4 \mathrm{~h}$, the transfection medium was replaced with a medium containing 2HE-5NMe. A series of 100 transfection-positive cells (as indicated by GFP fluorescence) were imaged and checked for foci after $24 \mathrm{~h}$. All experiments were carried out in triplicate. For disruption of preformed nuclear foci by 2HE-5NMe, COS7 cells were treated with the compound $24 \mathrm{~h}$ post-transfection. After an additional $24 \mathrm{~h}$, nuclear foci were imaged as described above. 


\section{Quantifying RANT Products by Western Blotting}

COS7 cells in 96-well plates were transfected with $200 \mathrm{ng}$ of a plasmid encoding $(\mathrm{CGG})_{88^{-}}$ $\mathrm{GFP}^{17}$ using Lipofectamine 2000 per the manufacturer's standard protocol. Approximately 5 $\mathrm{h}$ post-transfection, the transfection cocktail was removed and replaced with growth medium containing compound, and the cells were incubated at $37^{\circ} \mathrm{C}$ for $18 \mathrm{~h}$. Cells were lysed in the plate using $100 \mu \mathrm{L} /$ well of MPER Mammalian Protein Extraction Reagent (Pierce Biotechnology) containing $1 \mu \mathrm{L}$ of Halt Protease Inhibitor Cocktail (Thermo Scientific). Cellular proteins were separated by SDS-PAGE and transferred to a PVDF membrane. Western blotting was completed using anti-GFP (Santa Cruz) or anti- $\beta$-actin (SigmaAldrich) as primary antibodies and anti-IgG-horseradish peroxidase conjugate as the secondary antibody. A chemiluminescent signal was generated by SuperSignal West Pico Chemiluminescent substrate (Thermo Scientific), and the blot was imaged using X-ray film (PHENIX Research).

\section{Quantification of FMRpolyG-GFP Inclusions}

FMRpolyG inclusions were quantified as previously described.(17) Briefly, COS7 cells in six-well plates were transfected with $1 \mu \mathrm{g}$ of CGG100 + 1-GFP plasmid with Lipofectamine 2000. Approximately $4 \mathrm{~h}$ later, the transfection cocktail was removed and replaced with growth medium containing vehicle (DMSO) or drug (1a) at the indicated concentrations. Cells were imaged on an epifluourescent microscope 24 or $48 \mathrm{~h}$ after treatment. Images were then processed to remove background signal. Transfection positive cells $(n=100)$ in each well were manually graded as "with inclusions" or "no inclusions." The scorer was not blinded to treatment. Two wells per group in each of three independent experiments for both time points were counted, and total numbers across all three experiments were pooled. Statistical significance was assessed via a Kruskal-Wallis ANOVA test applied to data from both the 24 and $48 \mathrm{~h}$ time points. Significance of individual time points and treatment doses was assessed by Fisher's exact test with Bonferroni correction for multiple comparisons.

\section{Polysome Profiling}

To study the effects of compounds on ribosome loading onto $\mathrm{r}(\mathrm{CGG})^{\mathrm{exp}}$, polysome profiling was performed as previously reported.(21) Primer sequences for GFP and $\beta$-actin mRNAs are provided in Table S1.

\section{Supplementary Material}

Refer to Web version on PubMed Central for supplementary material.

\section{Acknowledgments}

This work was funded by the National Institutes of Health (DP1 NS096898 to M.D.D. and 1R01 NS086810 to P.K.T.), U.S. Department of Veterans Affairs (BLR\&D 1I21BX001841 to P.K.T.), a FRAXA postdoctoral fellowship to W.-Y.Y., and The Scripps Research Institute. M.D.D. was a Camille \& Henry Dreyfus TeacherScholar. 


\section{References}

1. Atkins, JF., Gesteland, RF., Cech, TR. RNA Worlds: From Life's Orignis to Diversity in Gene Regulation. Cold Spring Harbor Laboratory Press; Cold Spring Harbor, NY: 2011.

2. Cooper TA, Wan L, Dreyfuss G. RNA and disease Cell. 2009; 136:777-793. DOI: 10.1016/j.cell. 2009.02.011

3. Orr HT, Zoghbi HY. Trinucleotide repeat disorders. Annu Rev Neurosci. 2007; 30:575-621. DOI: 10.1146/annurev.neuro.29.051605.113042 [PubMed: 17417937]

4. Pushechnikov A, Lee MM, Childs-Disney JL, Sobczak K, French JM, Thornton CA, Disney MD. Rational design of ligands targeting triplet repeating transcripts that cause RNA dominant disease: application to myotonic muscular dystrophy type 1 and spinocerebellar ataxia type 3. J Am Chem Soc. 2009; 131:9767-9779. DOI: 10.1021/ja9020149 [PubMed: 19552411]

5. Coffey SM, Cook K, Tartaglia N, Tassone F, Nguyen DV, Pan R, Bronsky HE, Yuhas J, Borodyanskaya M, Grigsby J, Doerflinger M, Hagerman PJ, Hagerman RJ. Expanded clinical phenotype of women with the FMR1 premutation. Am J Med Genet Part A. 2008; 146A:10091016. DOI: 10.1002/ajmg.a.32060 [PubMed: 18348275]

6. Rodriguez-Revenga L, Madrigal I, Pagonabarraga J, Xuncla M, Badenas C, Kulisevsky J, Gomez B, Mila M. Penetrance of $F M R 1$ premutation associated pathologies in fragile X syndrome families. Eur Eur J Hum Genet. 2009; 17:1359-1362. DOI: 10.1038/ejhg.2009.51 [PubMed: 19367323]

7. Amiri K, Hagerman RJ, Hagerman PJ. Fragile X associated tremor/ataxia syndrome: an aging face of the fragile X gene. Arch Neurol. 2008; 65:19-25. DOI: 10.1001/archneurol.2007.30 [PubMed: 18195136]

8. Berry-Kravis E, Abrams L, Coffey SM, Hall DA, Greco C, Gane LW, Grigsby J, Bourgeois JA, Finucane B, Jacquemont S, Brunberg JA, Zhang L, Lin J, Tassone F, Hagerman PJ, Hagerman RJ, Leehey MA. Fragile X-associated tremor/ataxia syndrome: Clinical features, genetics, and testing guidelines. Mov Disord. 2007; 22:2018-2030. DOI: 10.1002/mds.21493 [PubMed: 17618523]

9. Jacquemont S, Hagerman RJ, Hagerman PJ, Leehey MA. Fragile-X syndrome and fragile Xassociated tremor/ataxia syndrome: two faces of FMR1. Lancet Neurol. 2007; 6:45-55. DOI: 10.1016/S1474-4422(06)70676-7 [PubMed: 17166801]

10. Sellier C, Rau F, Liu Y, Tassone F, Hukema RK, Gattoni R, Schneider A, Richard S, Willemsen R, Elliott DJ, Hagerman PJ, Charlet-Berguerand N. Sam68 sequestration and partial loss of function are associated with splicing alterations in FXTAS patients. EMBO J. 2010; 29:1248-1261. DOI: 10.1038/emboj.2010.21 [PubMed: 20186122]

11. Willemsen R, Hoogeveen-Westerveld M, Reis S, Holstege J, Severijnen LA, Nieuwenhuizen IM, Schrier M, van Unen L, Tassone F, Hoogeveen AT, Hagerman PJ, Mientjes EJ, Oostra BA. The FMR1 CGG repeat mouse displays ubiquitin-positive intranuclear neuronal inclusions; implications for the cerebellar tremor/ataxia syndrome. Hum Mol Genet. 2003; 12:949-959. DOI: 10.1093/hmg/ddg114 [PubMed: 12700164]

12. Jin P, Zarnescu DC, Zhang F, Pearson CE, Lucchesi JC, Moses K, Warren ST. RNA-mediated neurodegeneration caused by the fragile $\mathrm{X}$ premutation $\mathrm{rCGG}$ repeats in Drosophila. Neuron. 2003; 39:739-747. DOI: 10.1016/S0896-6273(03)00533-6 [PubMed: 12948442]

13. Tassone F, Hagerman RJ, Garcia-Arocena D, Khandjian EW, Greco CM, Hagerman PJ. Intranuclear inclusions in neural cells with premutation alleles in fragile $\mathrm{X}$ associated tremor/ ataxia syndrome. J Med Genet. 2004; 41:e43.doi: 10.1136/jmg.2003.012518 [PubMed: 15060119]

14. Greco CM, Berman RF, Martin RM, Tassone F, Schwartz PH, Chang A, Trapp BD, Iwahashi C, Brunberg J, Grigsby J, Hessl D, Becker EJ, Papazian J, Leehey MA, Hagerman RJ, Hagerman PJ. Neuropathology of fragile X-associated tremor/ataxia syndrome (FXTAS). Brain. 2006; 129:243255. [PubMed: 16332642]

15. Sellier C, Freyermuth F, Tabet R, Tran T, He F, Ruffenach F, Alunni V, Moine H, Thibault C, Page A, Tassone F, Willemsen R, Disney MD, Hagerman PJ, Todd PK, Charlet-Berguerand N. Sequestration of DROSHA and DGCR8 by expanded CGG RNA repeats alters microRNA processing in fragile X-associated tremor/ataxia syndrome. Cell Rep. 2013; 3:869-880. DOI: 10.1016/j.celrep.2013.02.004 [PubMed: 23478018] 
16. Chawla G, Lin CH, Han A, Shiue L, Ares M Jr, Black DL. Sam68 regulates a set of alternatively spliced exons during neurogenesis. Mol Cell Biol. 2009; 29:201-213. DOI: 10.1128/MCB. 01349-08 [PubMed: 18936165]

17. Todd PK, Oh SY, Krans A, He F, Sellier C, Frazer M, Renoux AJ, Chen KC, Scaglione KM, Basrur V, Elenitoba-Johnson K, Vonsattel JP, Louis ED, Sutton MA, Taylor JP, Mills RE, CharletBerguerand N, Paulson HL. CGG repeat-associated translation mediates neurodegeneration in fragile X tremor ataxia syndrome. Neuron. 2013; 78:440-455. DOI: 10.1016/j.neuron.2013.03.026 [PubMed: 23602499]

18. Zu T, Gibbens B, Doty NS, Gomes-Pereira M, Huguet A, Stone MD, Margolis J, Peterson M, Markowski TW, Ingram MAC, Nan Z, Forster C, Low WC, Schoser B, Somia NV, Clark HB, Schmechel S, Bitterman PB, Gourdon G, Swanson MS, Moseley M, Ranum LPW. Non-ATGinitiated translation directed by microsatellite expansions. Proc Natl Acad Sci U S A. 2011; 108:260-265. DOI: 10.1073/pnas.1013343108 [PubMed: 21173221]

19. Pearson CE. Repeat associated non-ATG translation initiation: one DNA, two transcripts, seven reading frames, potentially nine toxic entities! PLoS Genet. 2011; 7:e1002018.doi: 10.1371/ journal.pgen.1002018 [PubMed: 21423665]

20. Disney MD, Liu B, Yang W, Sellier C, Tran T, Charlet-Berguerand N, Childs-Disney JL. A small molecule that targets $\mathrm{r}(\mathrm{CGG})^{\mathrm{exp}}$ and improves defects in fragile $\mathrm{X}$-associated tremor ataxia syndrome. ACS Chem Biol. 2012; 7:1711-1718. DOI: 10.1021/cb300135h [PubMed: 22948243]

21. Yang WY, Wilson HD, Velagapudi SP, Disney MD. Inhibition of non-ATG translational events in cells via covalent small molecules targeting RNA. J Am Chem Soc. 2015; 137:5336-5345. DOI: 10.1021/ja507448y [PubMed: 25825793]

22. Chaires, JB., Ragazzon, PA., Garbett, NC. Curr Protoc Nucleic Acid Chem. Vol. Chapter 8. John Wiley \& Sons, Inc; Hoboken, NJ: 2003. A competition dialysis assay for the study of structureselective ligand binding to nucleic acids.

23. McDowell JA, Turner DH. Investigation of the structural basis for thermodynamic stabilities of tandem GU mismatches: solution structure of (rGAGGUCUC) 2 by two-dimensional NMR and simulated annealing. Biochemistry. 1996; 35:14077-14089. DOI: 10.1021/bi9615710 [PubMed: 8916893]

24. Nagaraj N, Wisniewski JR, Geiger T, Cox J, Kircher M, Kelso J, Pääbo S, Mann M. Deep proteome and transcriptome mapping of a human cancer cell line. Mol Syst Biol. 2011; 7:548.doi: 10.1038/msb.2011.81 [PubMed: 22068331]

25. Lefever S, Vandesompele J, Speleman F, Pattyn F. RTPrimerDB: the portal for real-time PCR primers and probes. Nucleic Acids Res. 2009; 37:D942-D945. DOI: 10.1093/nar/gkn777 [PubMed: 18948285]

26. Strack RL, Disney MD, Jaffrey SR. A superfolding Spinach2 reveals the dynamic nature of trinucleotide repeat-containing RNA. Nat Methods. 2013; 10:1219-1224. DOI: 10.1038/nmeth. 2701 [PubMed: 24162923]

27. Lee MM, Childs-Disney JL, Pushechnikov A, French JM, Sobczak K, Thornton CA, Disney MD. Controlling the specificity of modularly assembled small molecules for RNA via ligand module spacing: targeting the RNAs that cause myotonic muscular dystrophy. J Am Chem Soc. 2009; 131:17464-17472. DOI: 10.1021/ja906877y [PubMed: 19904940]

28. Rzuczek SG, Gao Y, Tang ZZ, Thornton CA, Kodadek T, Disney MD. Features of modularly assembled compounds that impart bioactivity against an RNA target. ACS Chem Biol. 2013; 8:2312-2321. DOI: 10.1021/cb400265y [PubMed: 24032410]

29. Tran T, Childs-Disney JL, Liu B, Guan L, Rzuczek S, Disney MD. Targeting the r(CGG) repeats that cause FXTAS with modularly assembled small molecules and oligonucleotides. ACS Chem Biol. 2014; 9:904-912. DOI: 10.1021/cb400875u [PubMed: 24506227]

30. Guan L, Disney MD. Covalent small molecule-RNA complex formation enables cellular profiling of small molecule-RNA interactions. Angew Chem Int Ed. 2013; 52:10010-10013. DOI: 10.1002/ anie. 201301639

31. Chen LS, Tassone F, Sahota P, Hagerman PJ. The (CGG)n repeat element within the $5^{\prime}$ untranslated region of the FMR 1 message provides both positive and negative cis effects on in vivo translation of a downstream reporter. Hum Mol Genet. 2003; 12:3067-3074. DOI: 10.1093/hmg/ ddg331 [PubMed: 14519687] 
A

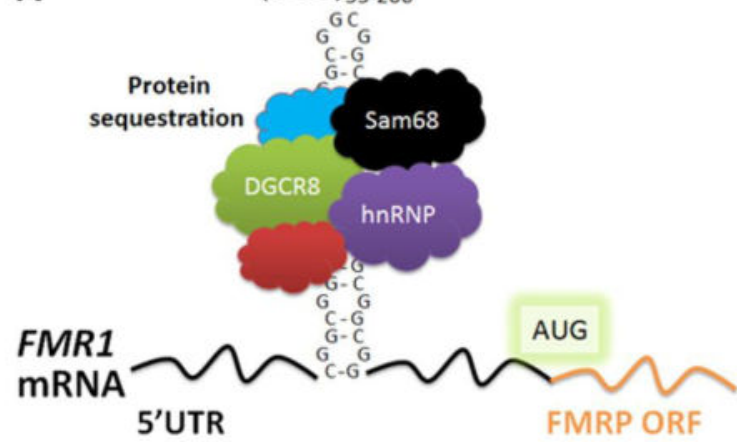

B

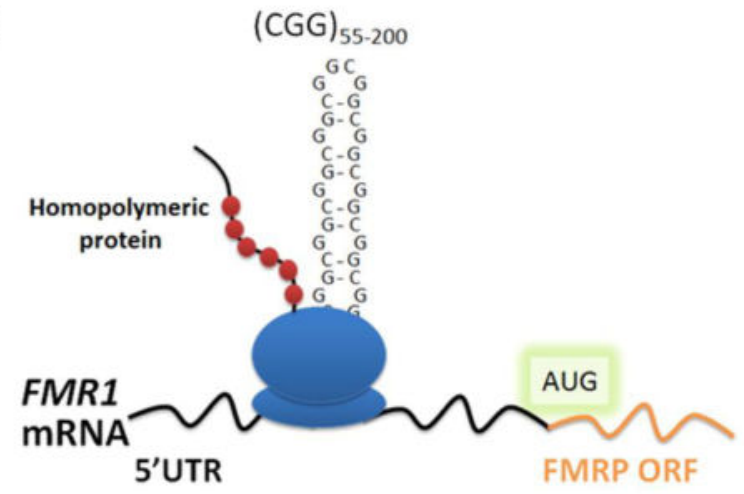

Gain of function

RAN translation

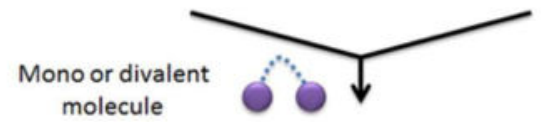

C

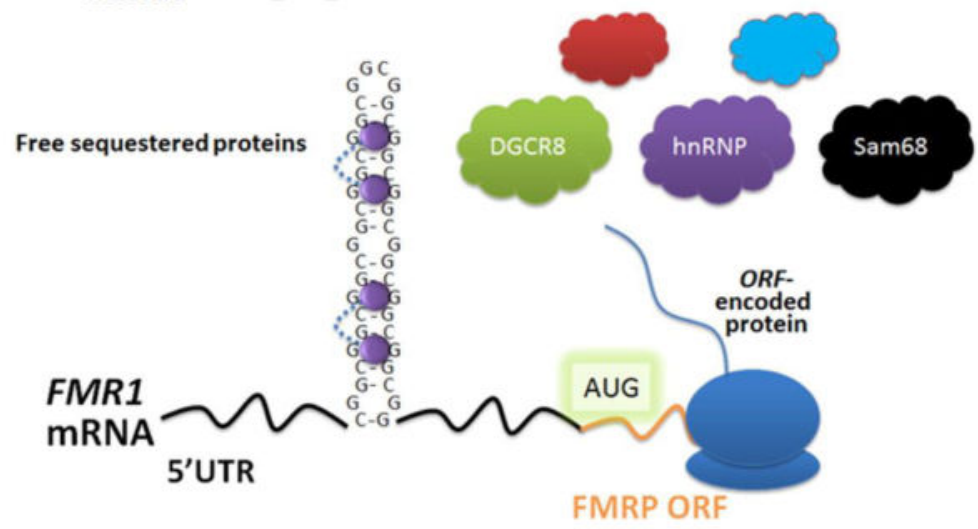

Figure 1.

Modes of toxicity associated with $\mathrm{r}(\mathrm{CGG})^{\mathrm{exp}}$, the causative agent of FXTAS. (A) The repeating RNA folds into a hairpin structure that binds and sequesters proteins that regulate RNA processing events. (B) Repeating transcripts are translated without a start codon in a mechanism called repeat associated non-ATG translation (RANT), producing toxic polymeric proteins that contribute to pathogenesis. (C) Small molecules that bind to $\mathrm{r}(\mathrm{CGG})^{\mathrm{exp}}$ free bound proteins, improve defects in RNA processing, and inhibit production of RAN, but not canonical, translation products. 
A

C

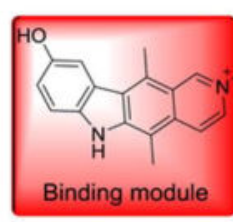

1a-CA-Biotin

D

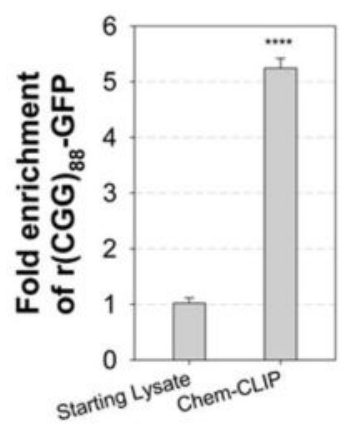

Figure 2.
B

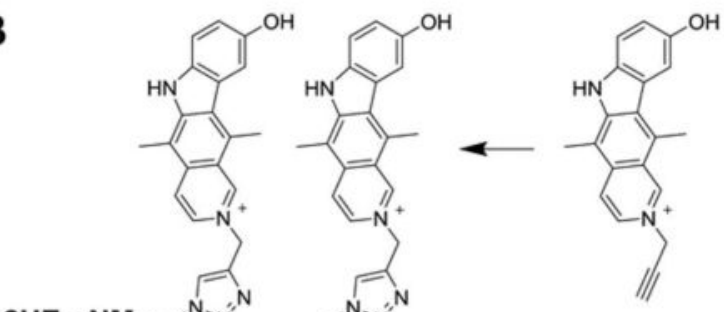

HE-alkyne

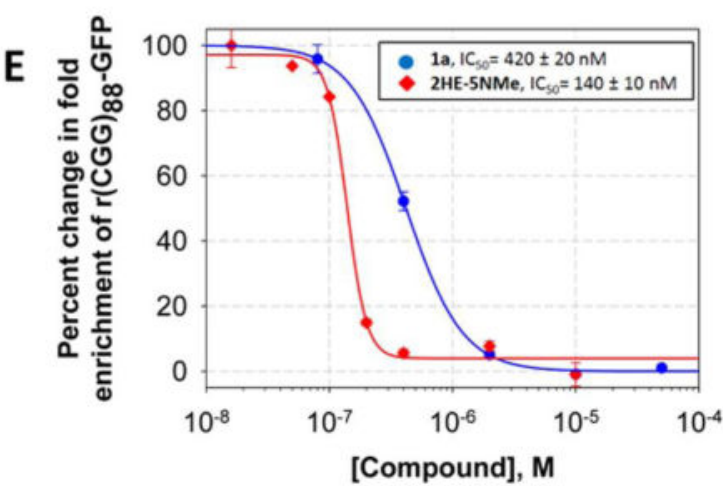

Structures of designer compounds and validation of their binding to and occupancy of $\mathrm{r}(\mathrm{CGG})^{\mathrm{exp}}$. (A) Structure of 1a. (B) Modularly assembled compounds thereof, 2HE-nNMe. (C) Structure of 1a-CA-Biotin used as the Chem-CLIP probe, allowing pull-down or $\mathrm{r}(\mathrm{CGG})_{88}$-GFP transcripts in cells. (D) Results of Chem-CLIP. A 5-fold enrichment of $\mathrm{r}(\mathrm{CGG})_{88}$-GFP was observed in the pulled down fractions from cells treated with 1a-CABiotin. (E) Results of C-Chem-CLIP. Co-treatment of cells with 1a or 2HE-5NMe and 1aCA-Biotin $(2.5 \mu \mathrm{M})$ inhibited the probe from binding to the RNA target. Target occupancy of $1 \mathbf{a}$ and $2 \mathrm{HE}-5 \mathrm{NMe}$ compounds for $\mathrm{r}(\mathrm{CGG})_{88}$-GFP in cells was determined by measuring the $\mathrm{IC}_{50}$ for inhibition of the 1a-CA-Biotin reaction with $\mathrm{r}(\mathrm{CGG})_{88}$-GFP. $* * * * p<0.0001$, as determined by a Student's $t$ test. 


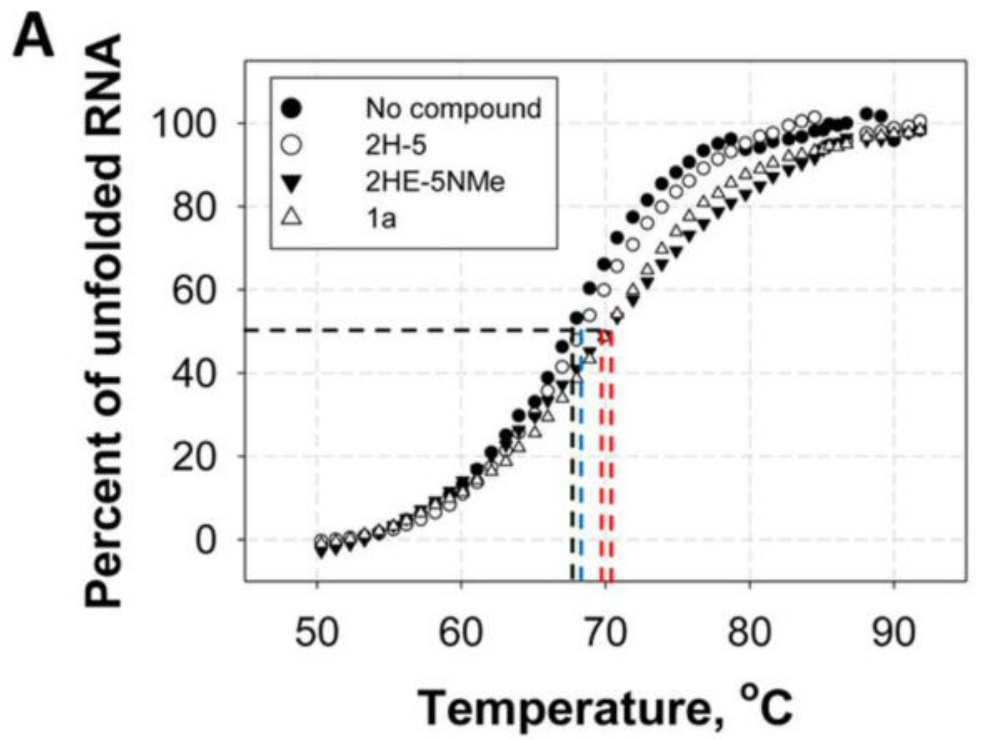

B

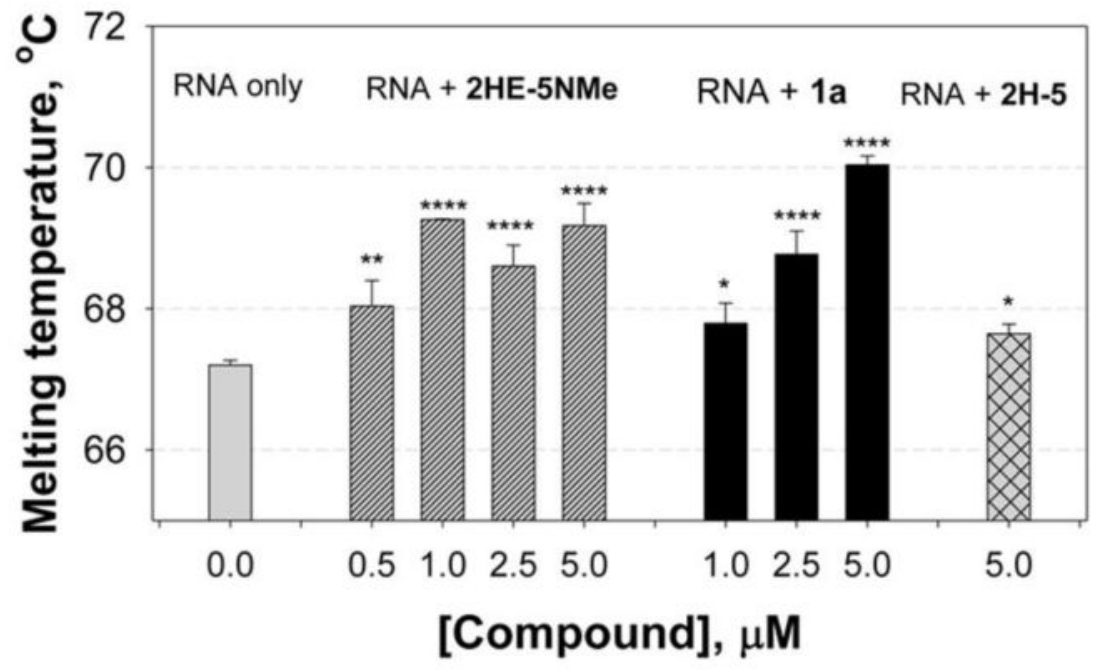

Figure 3.

1a and 2HE-5NMe shown to increase the thermal stability of $\mathrm{r}(\mathrm{CGG})_{12}$, which has five $1 \times$ 1 nucleotide GG internal loops. Optical melting experiments were completed with $1 \mu \mathrm{M}$ $\mathrm{r}(\mathrm{CGG})_{12}$ and the indicated concentrations of compound. (A) Representative plots of optical melting experiments $([$ compound $]=5 \mu \mathrm{M})$. $(\mathrm{B})$ Plot of the melting temperature of $\mathrm{r}(\mathrm{CGG})_{12}$ as a function of 2HE-5NMe or 1 a concentration. $* p<0.05, * * p<0.01, * * * p<0.001$, and $* * * * p<0.0001$ as determined by a Student $t$ test.

ACS Chem Biol. Author manuscript; available in PMC 2017 September 16. 

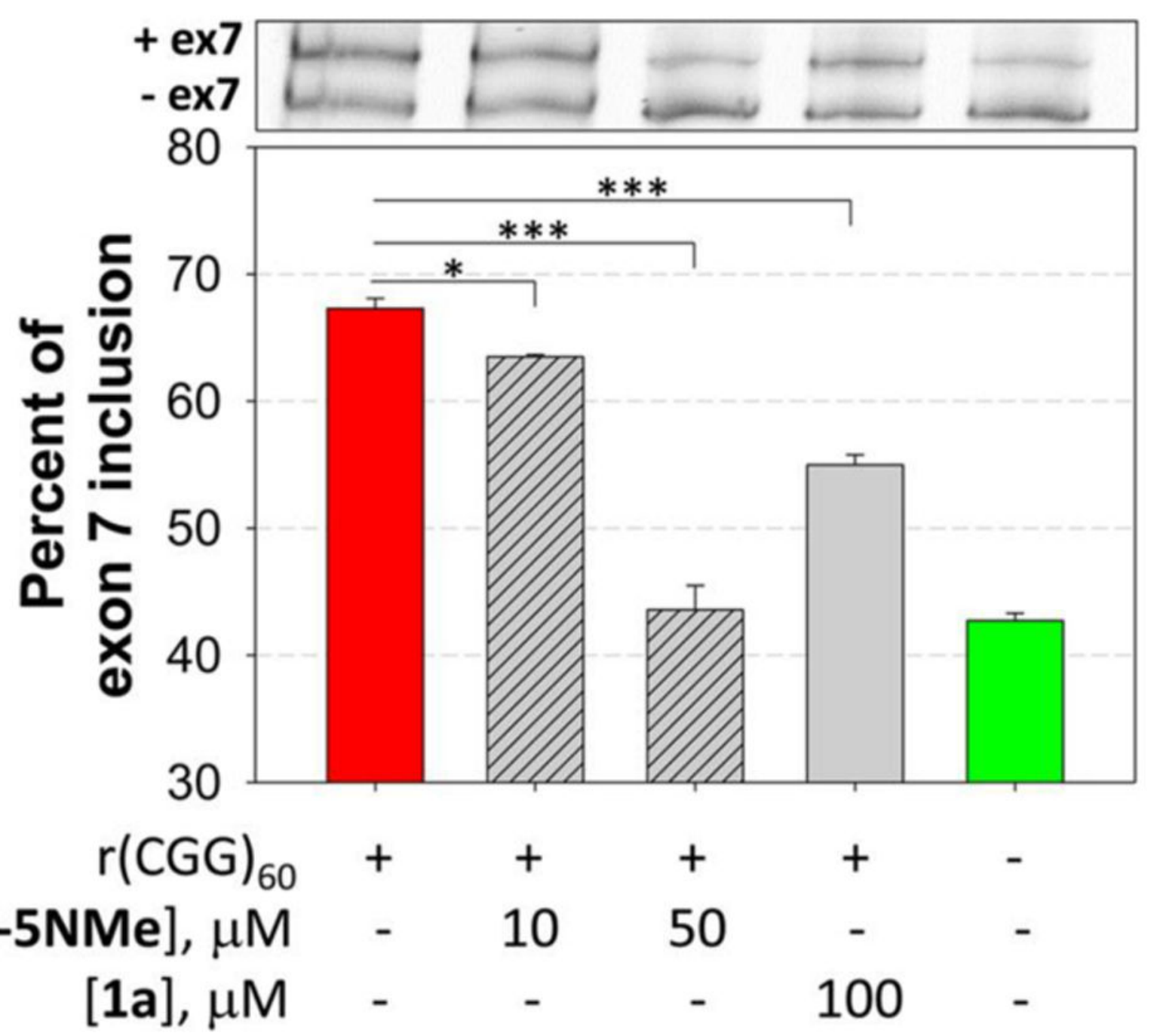

Figure 4.

2HE-5NMe shown to improve FXTAS-associated pre-mRNA splicing defects in a cellular model. Top, representative gel image of the alternative pre-mRNA splicing of the SMN2 mini-gene in the presence and absence of $\mathrm{r}(\mathrm{CGG})^{\exp }$ upon treatment with 2HE-5NMe or 1a. Bottom, plot of the quantification of $S M N 2$ exon 7 inclusion upon compound treatment. * $p$ $<0.05$ and ${ }^{* * *} p<0.001$, as determined by a Student $t$ test. 
A Inhibition of nuclear foci

Control 2HE-5NMe (50 $\mu \mathrm{M})$
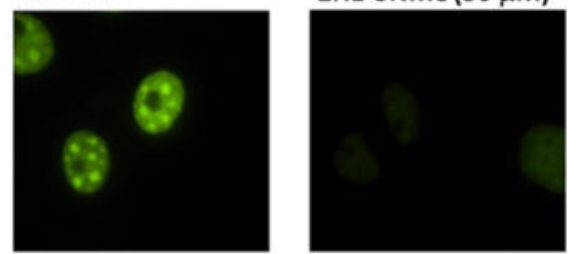

Disruption of nuclear foci Control 2HE-5NMe (50 $\mu \mathrm{M})$
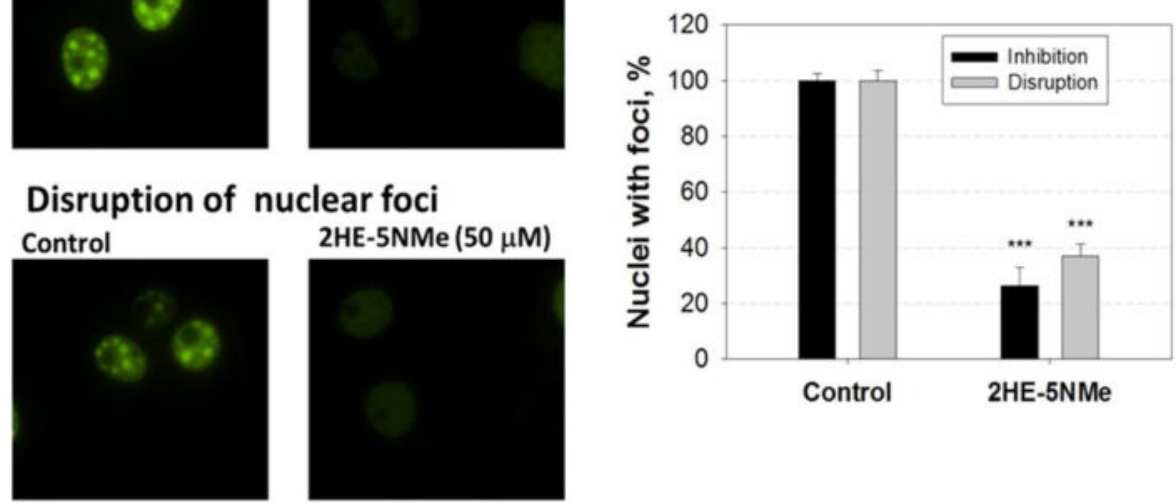

B
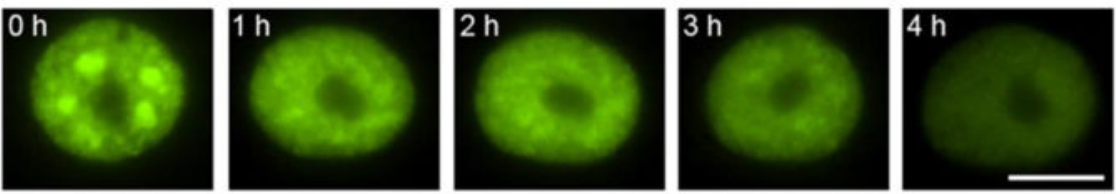

C
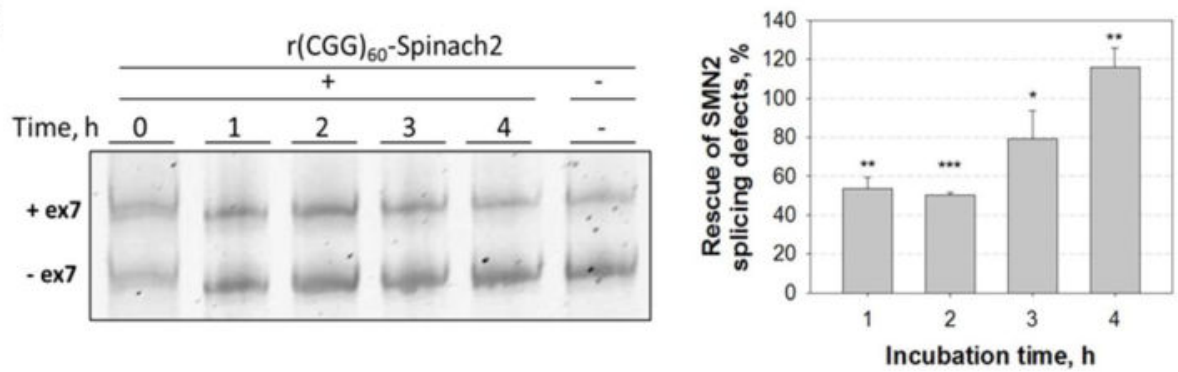

Figure 5.

Effect of 2HE-5NMe on r(CGG) $)^{\text {exp }}$-containing nuclear foci. Previously, it was shown that 1a inhibits foci formation but cannot disrupt pre-existing foci.(26) (A) Top left, inhibition of nuclear foci formation by 2HE-5NMe. Bottom left, disruption of nuclear foci formation by 2HE-5NMe. Right, quantification of nuclear foci in 2HE-5NMe-treated cells. (B and C) Time course on the effects of $\mathbf{2 H E - 5 N M e ~}(50 \mu \mathrm{M})$ on foci formation and improvement of alternative pre-mRNA splicing defects. (B) Representative images of nuclear foci at different times. Scale bar, $10 \mu \mathrm{m}$. (C) Representative gel images of $S M N 2$ mini-gene splicing products at different times (left) and their quantification (right). $* p<0.05, * * p<0.001$, and *** $p<0.0001$ as determined by a Student $t$ test. 
A

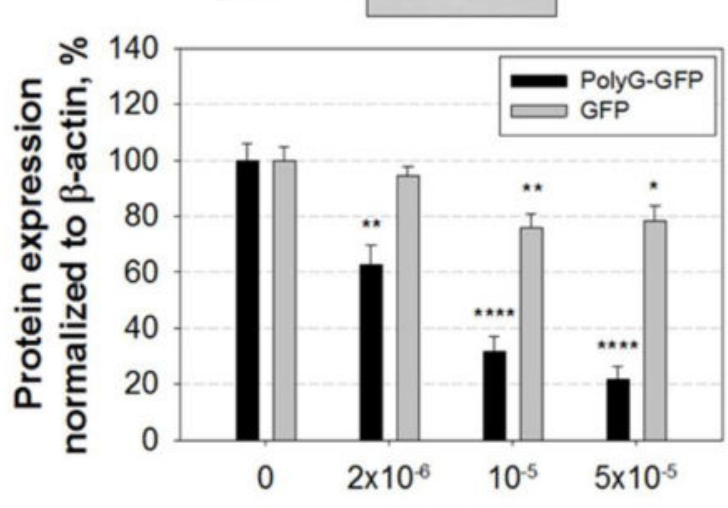

[1a], M

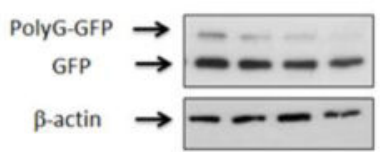

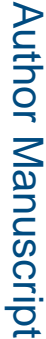

B
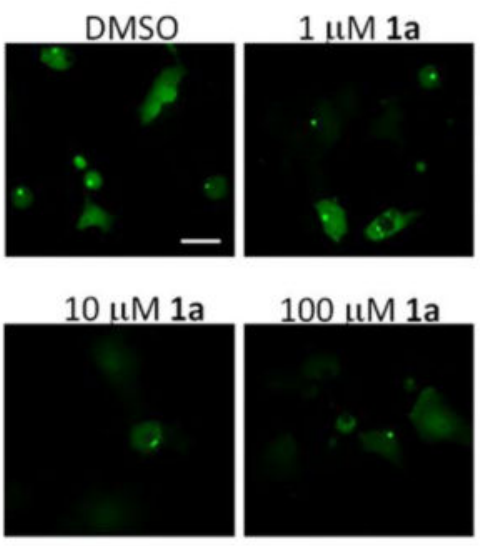
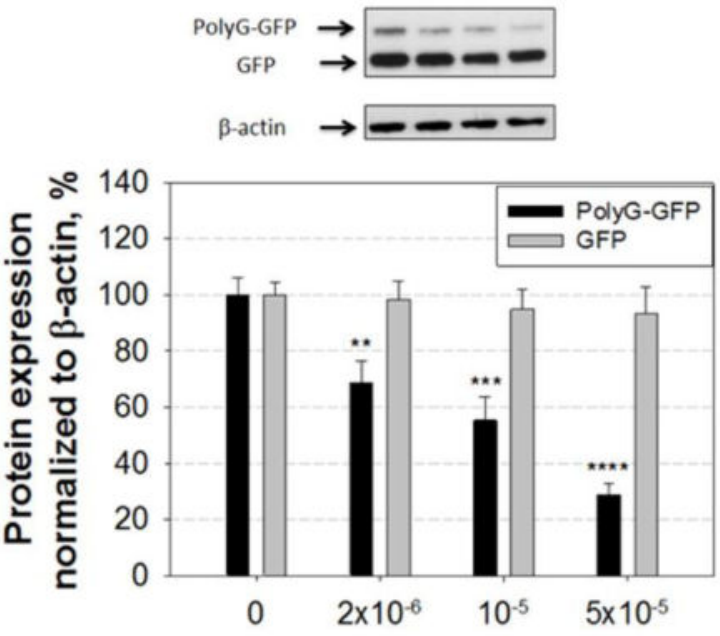

[2HE-5NMe], M

Figure 6.

Inhibition of RANT and accumulation of RANT products in nuclear inclusions. (A) 1a and 2HE-5NMe inhibit RANT of r(CGG) $88^{-}$-GFP. 1a (left) and 2HE-5NMe (right) inhibit RANT of $\mathrm{r}(\mathrm{CGG})^{\text {exp }}$ but not canonical translation of the downstream ORF, which encodes GFP, as determined by Western blotting. $P$ values were determined by a Student $t$ test. (B) 1a decreases FMRpolyG-GFP accumulation and aggregation. Left, representative images from COS7 cells expressing (CGG) ${ }_{90}$-GFP for $48 \mathrm{~h}$ in the presence of vehicle (DMSO) or compound 1a at the indicated concentration. Aggregates of FMRpolyG-GFP fusion protein accumulate in these cells and are reduced in the presence of 1a. Right, percent of FMRpolyG-GFP inclusions 24 (blue) and 48 (red) h post treatment with vehicle or 1a. Data were pooled from three independent experiments. Drug treatment was associated with a significant reduction in inclusion number. $P$ values were determined by Fisher's exact test. $* p<0.05 ; * * p<0.01 ; * * * p<0.001 ;$ and $* * * * p<0.0001$. 
A

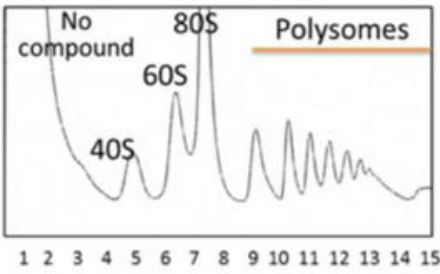

B

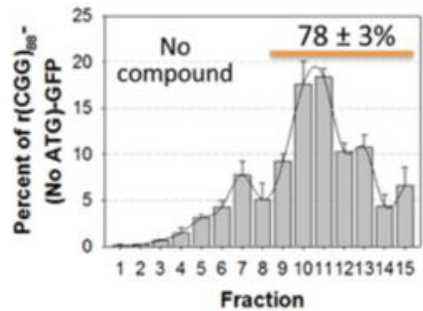

C

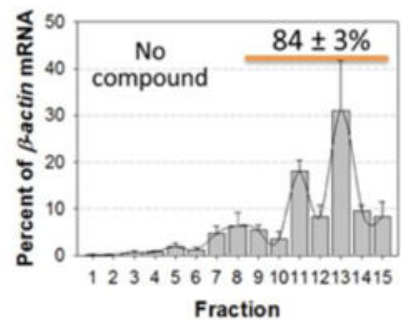

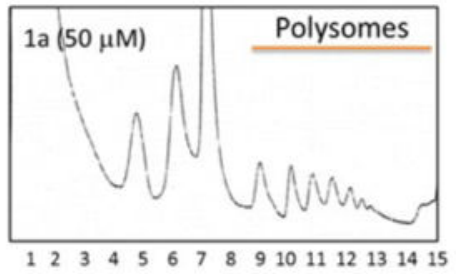
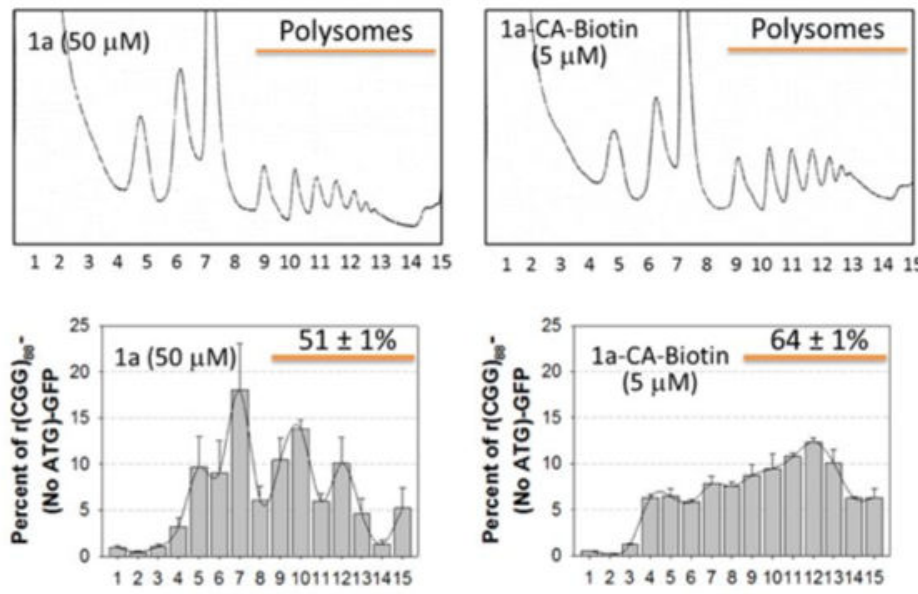

Fraction

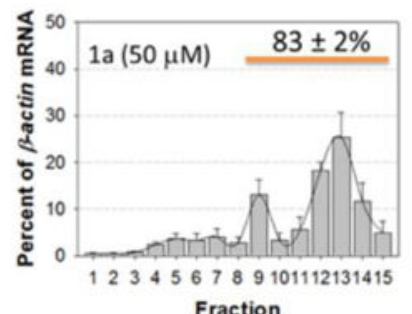

Fraction

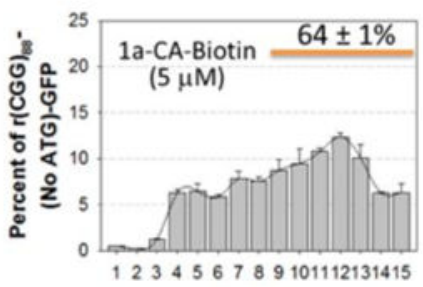

Fraction

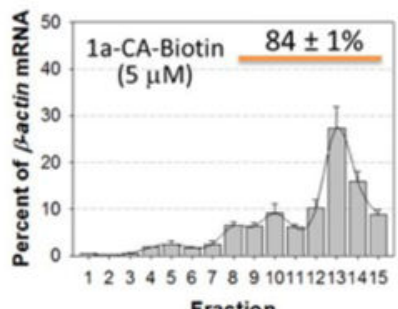

D

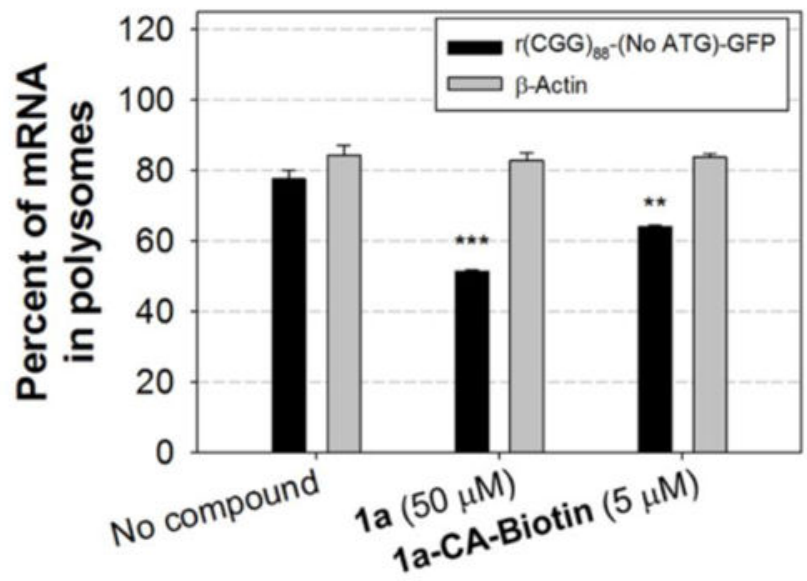

Compound

Figure 7.

Polysome profiling to study ribosome loading onto $(\mathrm{CGG})^{\exp }$ in the presence and absence of compound. (A) Sucrose gradients for untreated, 1a- or 1a-CA-Biotin-treated cells. (B) Distribution of $\mathrm{r}(\mathrm{CGG})_{88}$-(No ATG)-GFP. (C) Distribution of $\beta$-actin mRNA. (D) Quantification of the results shown in B and C. 

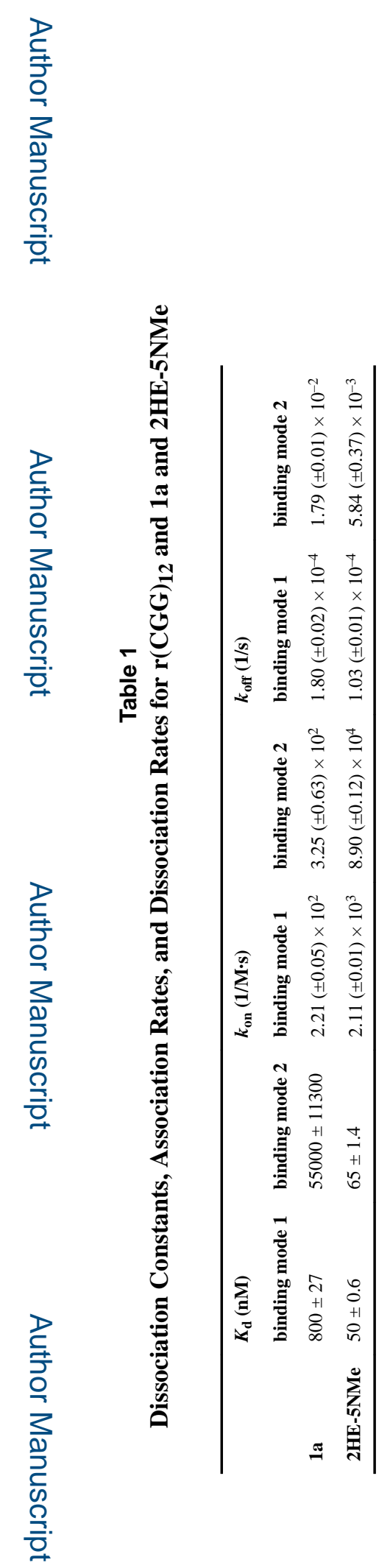

ACS Chem Biol. Author manuscript; available in PMC 2017 September 16. 
Table 2

Thermodynamic Parameters from Melt Curves of $\mathbf{r}(\mathrm{CGG})_{12}{ }^{a}$

\begin{tabular}{lllll}
\hline & $\boldsymbol{\Delta H}(\mathbf{k c a l} / \mathbf{m o l})$ & $\Delta \boldsymbol{S}(\mathbf{c a l} / \mathbf{K} \cdot \mathbf{~ m o l})$ & $\Delta \boldsymbol{G}\left(\mathbf{k c a l} / \mathbf{m o l}, \mathbf{3 7}{ }^{\circ} \mathbf{C}\right)$ & $\mathbf{T m}\left({ }^{\circ} \mathbf{C}\right)$ \\
$\mathrm{r}(\mathrm{CGG})_{12}$ only & $-69.0 \pm 1.7$ & $-203 \pm 5$ & $-6.13 \pm 0.15$ & $67.2 \pm 0.1$ \\
$\mathrm{r}(\mathrm{CGG})_{12}+\mathbf{2 H E}-5 \mathbf{N M e}$ & $-74.9 \pm 1.1$ & $-219 \pm 3$ & $-7.04 \pm 0.13$ & $69.2 \pm 0.3$ \\
$\mathrm{r}(\mathrm{CGG})_{12}+\mathbf{1 a}$ & $-77.1 \pm 0.1$ & $-225 \pm 1$ & $-7.48 \pm 0.02$ & $70.2 \pm 0.1$ \\
$\mathrm{r}(\mathrm{CGG})_{12}+\mathbf{2 H - 5}$ & $-69.8 \pm 0.1$ & $-204 \pm 0.2$ & $-6.40 \pm 0.01$ & $67.6 \pm 0.1$ \\
\hline
\end{tabular}

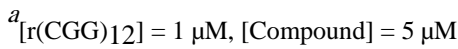

